\title{
Isolation and characterization of the first phage infecting ecologically important marine bacteria Erythrobacter
}

\author{
Longfei Lu, Lanlan Cai, Nianzhi Jiao and Rui Zhang*
}

\begin{abstract}
Background: Erythrobacter comprises a widespread and ecologically significant genus of marine bacteria. However, no phage infecting Erythrobacter spp. has been reported to date. This study describes the isolation and characterization of phage $v B_{-}$EliS-R6L from Erythrobacter.

Methods: Standard virus enrichment and double-layer agar methods were used to isolate and characterize the phage. Morphology was observed by transmission electron microscopy, and a one-step growth curve assay was performed. The phage genome was sequenced using the Illumina Miseq platform and annotated using standard bioinformatics tools. Phylogenetic analyses were performed based on the deduced amino acid sequences of terminase, endolysin, portal protein, and major capsid protein, and genome recruitment analysis was conducted using Jiulong River Estuary Virome, Pacific Ocean Virome and Global Ocean Survey databases.
\end{abstract}

Results: A novel phage, $v B$ _EliS-R6L, from coastal waters of Xiamen, China, was isolated and found to infect the marine bacterium Erythrobacter litoralis DSM 8509. Morphological observation and genome analysis revealed that phage vB_ EliS-R6L is a siphovirus with a 65.7-kb genome that encodes 108 putative gene products. The phage exhibits growth at a wide range of temperature and $\mathrm{pH}$ conditions. Genes encoding five methylase-related proteins were found in the genome, and recognition site predictions suggested its resistance to restriction-modification host systems. Genomic comparisons and phylogenetic analyses indicate that phage vB_EliS-R6L is distinct from other known phages.

Metagenomic recruitment analysis revealed that vB_EliS-R6L-like phages are widespread in marine environments, with likely distribution in coastal waters.

Conclusions: Isolation of the first Erythrobacter phage (VB_EliS-R6L) will contribute to our understanding of host-phage interactions, the ecology of marine Erythrobacter and viral metagenome annotation efforts.

Keywords: Erythrobacter, Marine, Siphovirus, Complete genome sequence

\section{Background}

As ecologically significant marine bacteria, Erythrobacter species (Alphaproteobacteria) are frequently detected in and isolated from nutrient-rich coastal seawaters [1-5]. Moreover, these microorganisms are thought to comprise a major fraction of the marine photoheterotrophs known as aerobic anoxygenic phototrophic bacteria (AAPBs), which play a significant role in the cycling of both organic and inorganic carbon in the ocean [2, 6-8]. To date, 19

\footnotetext{
* Correspondence: ruizhang@xmu.edu.cn

State Key Laboratory of Marine Environmental Science, Institute of Marine Microbes and Ecospheres, Xiamen University (Xiang'an), Xiamen, Fujian 361102, China
}

Erythrobacter species have been reported, and genomic marine Erythrobacter isolate was E longus DSM 6997, which was also the first AAPB identified [1]. In 1994, E. litoralis DSM 8509, containing the carotenoids bacteriorubixanthinal and erythroxanthin sulfate, was isolated from a marine cyanobacterial mat [12]. In addition, previous studies have demonstrated the potential use of Erythrobacter species (e.g., E. longus and E. citreus) for bioremediation of alkane contamination [13]. These species show high levels of resistance to tellurite and accumulate metallic tellurium crystals (e.g., E. longus) [14]; enantioselective 
epoxide hydrolase activity (e.g., E. longus) has also been reported [15].

Bacteriophages (viruses that infect bacteria) have important roles in the abundance, activity, and diversity of bacterial communities [16-18], and isolation and genomic characterization of phages greatly improves our understanding of the ecology and evolution of their hosts. For example, cyanophages (viruses that infect cyanobacteria) are active and abundant agents of mortality that directly affect the distribution and species composition of cyanobacteria in the aquatic environment $[17,19]$. In addition, investigation of SAR11 viruses helped to show that the highly abundant distribution of these viruses is the result of adaptation to resource competition [20]. It has also been suggested that roseophages (viruses that infect Roseobacter species, another representative genus of Alphaproteobacteria) can quickly alter the growth and abundance of their host population by changing their infection strategy and can shunt bacterial secondary production into the environmental dissolved-carbon pool [e.g., [21, 22].

Isolation of novel phages can assist with both the annotation of unidentified functional genes and in the discovery of diverse and widespread viral assemblages in aquatic and marine environments through virome database query [20, 22, 23]. However, no phage infecting Erythrobacter has been reported to date, hindering an integrated understanding of the life cycle of these microbes in the ocean. In this study, we report the first isolation of a novel phage infecting E. litoralis DSM 8509.

\section{Methods}

\section{Bacterial strains and growth conditions}

All of the bacterial strains used in this study are listed in Table 1. E. litoralis DSM 8509 and other strains were cultivated at $30{ }^{\circ} \mathrm{C}$ in $\mathrm{RO}$ medium, an artificial seawater medium containing $1 \mathrm{~g} / \mathrm{L}$ yeast extract, $1 \mathrm{~g} / \mathrm{L}$ tryptone, and $1 \mathrm{~g} / \mathrm{L}$ sodium acetate at $\mathrm{pH} 7.5$ [24].

\section{Isolation of the phage}

Phage vB_EliS-R6L was isolated from seawater obtained in March 2014 off the coast of Xiamen, China (118 $04^{\prime}$ E, $24^{\circ} 31^{\prime} \mathrm{N}$ ), using standard virus enrichment and doublelayer agar methods. Briefly, E. litoralis DSM 8509 $(100 \mathrm{~mL})$ was co-cultured with a pre-filtered $(0.22-\mu \mathrm{m}$ membrane filter; Millipore, USA) seawater sample $(20 \mathrm{~mL})$ for $24 \mathrm{~h}$ at $30{ }^{\circ} \mathrm{C}$. The culture was filtered again and serially diluted to determine phage activity using a double-layer agar method [25]. A single plaque was collected from the plate using a sterile pipette (Fisher, Canada) and then purified four successive times using the double-layer agar method. Following purification, stock cultures of the phage were prepared using sodium chloride-magnesium sulfate (SM) buffer $(100 \mathrm{mM} \mathrm{NaCl}$, $50 \mathrm{mM}$ Tris, $10 \mathrm{mM} \mathrm{MgSO}$, and $0.01 \%$ gelatin, $\mathrm{pH}$ 7.5) supplemented with several drops of chloroform and stored at $4{ }^{\circ} \mathrm{C}$ and $-80^{\circ} \mathrm{C}$.

\section{Transmission electron microscopy (TEM)}

For TEM analysis, 1 L of E. litoralis DSM 8509 culture $(\mathrm{OD} 600=0.5)$ was inoculated with the phage at a multiplicity of infection of 10 and cultivated for $24 \mathrm{~h}$ at $30{ }^{\circ} \mathrm{C}$. The mixture was centrifuged at $6000 \times g$ for $10 \mathrm{~min}$, and the upper aqueous phase was filtered through a $0.22-\mu \mathrm{m}$ membrane and precipitated with $10 \%(w / v)$ dissolved polyethylene glycol 8000 (containing $1 \mathrm{M} \mathrm{NaCl}$ ). After $>8 \mathrm{~h}$ at $4{ }^{\circ} \mathrm{C}$, the mixture was centrifuged at $10,000 \times g$ for $50 \mathrm{~min}$ at $4{ }^{\circ} \mathrm{C}$, and the pellet was gently resuspended in $5 \mathrm{~mL}$ of SM buffer. The phages were then purified by $\mathrm{CsCl}$ gradient ultra-centrifugation (gradient-density: $1.5 \mathrm{~g} / \mathrm{mL}, 200,000 \times g, 24 \mathrm{~h}, 4{ }^{\circ} \mathrm{C}$; Optima L-100 XP Ultracentrifuge, Beckman Coulter). The purified phage particles were collected and dialyzed twice in SM buffer; $20 \mu \mathrm{L}$ of suspension was added dropwise onto a copper grid and negatively stained with $2 \%$ aqueous uranyl acetate for $10 \mathrm{~min}$. Transmission electron micrographs were obtained using a JEM2100HC transmission electron microscope (JEOL, Japan) at an accelerating voltage of $120 \mathrm{kV}$. The phage size was calculated from at least 20 particles.

\section{Chloroform sensitivity}

To determine whether phage vB_EliS-R6L contains lipids, its sensitivity to chloroform was examined as described previously [26]. Briefly, $500 \mu \mathrm{L}$ of the phage suspension $\left(\sim 10^{9}\right.$ plaque forming units $\left.(\mathrm{PFU}) / \mathrm{mL}\right)$ were mixed with $5 \mu \mathrm{L}, 50 \mu \mathrm{L}$, or $500 \mu \mathrm{L}$ of chloroform, vigorously shaken for $2 \mathrm{~min}$, and then incubated at $30{ }^{\circ} \mathrm{C}$ for $30 \mathrm{~min}$. The samples were immediately diluted and plated for phage titration using double-layer agar plates inoculated with $E$. litoralis DSM 8509.

\section{Host range analysis}

To investigate the host range of phage vB_EliS-R6L, plaque assays were performed on 27 marine bacterial strains, including 21 Erythrobacter strains, two Citromicrobium strains, and one each of the genera Roseobacter, Dinoroseobacter, Lutibacterium, and Halomonas (Table 1). The host range was determined by adding $5 \mu \mathrm{L}$ of a diluted phage suspension $\left(\sim 10^{7} \mathrm{PFU} / \mathrm{mL}\right)$ dropwise onto the surface of double-layer agar plates inoculated with the bacterial strain of interest. The plates were incubated at $30{ }^{\circ} \mathrm{C}$ for up to 7 days, and plaque formation was assessed repeatedly during this period. The efficiency of plating (EOP) of susceptible strains was quantified by calculating the ratio of the PFU obtained with each phage-susceptible strain to the PFU obtained with E. litoralis DSM 8509. All assays were carried out in triplicate. 
Table 1 Bacterial strains used in the host-range test and their susceptibility to the phage vB_EliS-R6L

\begin{tabular}{|c|c|c|c|c|c|}
\hline Strains & $\begin{array}{l}\text { Best matched species } \\
\text { (\% Id of } 16 \mathrm{~S} \text { rDNA) }\end{array}$ & Source and location & References & $\begin{array}{l}\text { Susceptibility to } \\
\text { phage vB_EliS-R6L }\end{array}$ & $\begin{array}{l}\text { Efficiency of } \\
\text { plaquing }\end{array}$ \\
\hline Erythrobacter litoralis DSM 8509* & & Cyanobacterial mat, Netherlands & [12] & + & $100 \%$ \\
\hline Erythrobacter longus DSM 6997* & & $\begin{array}{l}\text { Seaweed Enteromorpha } \\
\text { linza, Japan }\end{array}$ & [1] & + & $94.74 \pm 3.78 \%$ \\
\hline Erythrobacter sp. JL 475 & & $\begin{array}{l}\text { Surface sea water, South China } \\
\text { sea, China }\end{array}$ & [11] & - & - \\
\hline JL 2316 & $\begin{array}{l}\text { Erythrobacter sp. CC-AMZ-30 } \\
\text { L (97.12) }\end{array}$ & Surface sea water, Pacific Ocean & & - & - \\
\hline JL 967 & $\begin{array}{l}\text { Erythrobacter sp. M71_W20 } \\
(100.00)\end{array}$ & $\begin{array}{l}\text { Surface sea water, Taiwan strait, } \\
\text { China }\end{array}$ & & - & - \\
\hline JL 1267 & $\begin{array}{l}\text { Erythrobacter sp. MON004 } \\
(100.00)\end{array}$ & $\begin{array}{l}\text { Surface sea water, South China } \\
\text { sea, China }\end{array}$ & & - & - \\
\hline JL 971-1 & $\begin{array}{l}\text { Erythrobacter nanhaisediminis } \\
\text { (99.33) }\end{array}$ & $\begin{array}{l}\text { Surface sea water, Taiwan strait, } \\
\text { China }\end{array}$ & & - & - \\
\hline JL 1059 & $\begin{array}{l}\text { Erythrobacter nanhaisediminis } \\
\text { T30 (99.22) }\end{array}$ & $\begin{array}{l}\text { Upper sea water }(150 \mathrm{~m}) \text {, West } \\
\text { Pacific Ocean }\end{array}$ & & - & - \\
\hline JL 1033 & $\begin{array}{l}\text { Erythrobacter nanhaisediminis } \\
\text { T30 (99.69) }\end{array}$ & $\begin{array}{l}\text { Upper sea water }(50 \mathrm{~m}) \text {, West } \\
\text { Pacific Ocean }\end{array}$ & & - & - \\
\hline JL 1302 & $\begin{array}{l}\text { Erythrobacter nanhaisediminis } \\
\text { T30 (97.79) }\end{array}$ & $\begin{array}{l}\text { Surface sea water, South China } \\
\text { sea, China }\end{array}$ & & - & - \\
\hline JL 1201 & $\begin{array}{l}\text { Erythrobacter vulgaris } \\
\text { TVG01-C004 (99.80) }\end{array}$ & $\begin{array}{l}\text { Surface sea water, West Pacific } \\
\text { Ocean }\end{array}$ & & - & - \\
\hline JL 274-1 & $\begin{array}{l}\text { Erythrobacter vulgaris } \\
022 \text { 2-10 (99.22) }\end{array}$ & Changjiang Estuary, China & & - & - \\
\hline JL 1500 & $\begin{array}{l}\text { Erythrobacter pelagi } \\
\text { UST081027-248 (99.90) }\end{array}$ & $\begin{array}{l}\text { Surface sea water, Beibu Gulf, } \\
\text { China }\end{array}$ & & - & - \\
\hline JL 1463 & $\begin{array}{l}\text { Erythrobacter pelagi } \\
\text { UST081027-248 (98.48) }\end{array}$ & $\begin{array}{l}\text { Surface sea water, South China } \\
\text { sea, China }\end{array}$ & & - & - \\
\hline JL 883 & $\begin{array}{l}\text { Erythrobacter flavus } \\
\text { SW-46 (99.79) }\end{array}$ & $\begin{array}{l}\text { Surface sea water, Taiwan strait, } \\
\text { China }\end{array}$ & & - & - \\
\hline JL 923 & $\begin{array}{l}\text { Erythrobacter flavus SW-46 } \\
(99.25)\end{array}$ & $\begin{array}{l}\text { Surface sea water, South China } \\
\text { sea, China }\end{array}$ & & - & - \\
\hline JL 1833 & $\begin{array}{l}\text { Erythrobacter flavus BL16 } \\
(100.00)\end{array}$ & $\begin{array}{l}\text { Bottom sea water, South China } \\
\text { sea, China }\end{array}$ & & - & - \\
\hline JL 1408 & $\begin{array}{l}\text { Erythrobacter flavus SW-46 } \\
(99.89)\end{array}$ & $\begin{array}{l}\text { Surface sea water, South China } \\
\text { sea, China }\end{array}$ & & - & - \\
\hline JL 917 & $\begin{array}{l}\text { Erythrobacter citreus RE35F/1 } \\
\text { (99.72) }\end{array}$ & $\begin{array}{l}\text { Surface sea water, Taiwan strait, } \\
\text { China }\end{array}$ & & - & - \\
\hline JL 1317 & $\begin{array}{l}\text { Erythrobacter flavus SW-46 } \\
(99.01)\end{array}$ & $\begin{array}{l}\text { Surface sea water, South China } \\
\text { sea, China }\end{array}$ & & - & - \\
\hline$J L$ 658-2 & $\begin{array}{l}\text { Erythrobacter citreus RE35F/1 } \\
\text { (99.66) }\end{array}$ & $\begin{array}{l}\text { Surface sea water, Taiwan strait, } \\
\text { China }\end{array}$ & & - & - \\
\hline $\begin{array}{l}\text { Roseobacter denitrificans } \\
\text { OCh114 DSM 7001* }\end{array}$ & & Seaweed, Japan & [52] & - & - \\
\hline Dinoroseobacter shibae DFL12* & & Cells of Prorocentrum lima & [53] & - & - \\
\hline $\begin{array}{l}\text { Citromicrobium bathyomarinum } \\
\text { JL } 354\end{array}$ & & $\begin{array}{l}\text { Surface sea water, South China } \\
\text { sea, China }\end{array}$ & & - & - \\
\hline JL 1363 & Citromicrobium sp. (100.00) & $\begin{array}{l}\text { Upper sea water ( } 50 \mathrm{~m}) \text {, South } \\
\text { China sea, China }\end{array}$ & & - & - \\
\hline JL 2210 & Lutibacterium sp. (100.00) & Surface sea water, Atlantic Ocean & & - & - \\
\hline JL 1614 & Halomonas sp. (100.00) & Surface sea water, Pacific Ocean & & - & - \\
\hline
\end{tabular}

*strains were purchased from DSMZ (the German Resource Center for Biological Material), Germany. +, cell lysis; -, no effect 


\section{One-step growth assays}

One-step growth curve experiments were performed as previously described [25, 27]. Briefly, mid-exponential phase E. litoralis DSM 8509 (optical density at $600 \mathrm{~nm}=0.3-0.5,100 \mathrm{~mL}$ ) was inoculated with phage at a multiplicity of infection of 0.01 and allowed to adsorb for $10 \mathrm{~min}$ at $30{ }^{\circ} \mathrm{C}$. The mixture was then centrifuged at $6000 \times g$ for $10 \mathrm{~min}$ to remove non-absorbed phage in the supernatant; the pelleted cells were resuspended in $100 \mathrm{~mL}$ of $\mathrm{RO}$ medium, followed by incubation at $30^{\circ} \mathrm{C}$. Two sets of duplicate samples were removed at 20-min intervals for $6 \mathrm{~h}$, and chloroform (1\% final concentration) was added to the second set to release the intracellular phage. The two samples were then diluted and immediately plated for phage titration using the double-layer agar plate method. Another set of cultures without phage inoculation served as the blank control. Samples for optical density $\left(\mathrm{OD}_{600}\right)$ measurements from both the treated and untreated cultures were removed at the 20-min intervals for $6 \mathrm{~h}$ and at 1-h intervals for the next $4 \mathrm{~h}$. The PFU of each sample was calculated by counting the plaques on the bacterial lawn. The assay was performed in triplicate.

\section{Thermal/pH stability}

To investigate the thermal stability of the phage, $1 \mathrm{~mL}$ of phage vB_EliS-R6L $\left(\sim 10^{7} \mathrm{PFU} / \mathrm{mL}\right)$ with SM buffer was incubated for $2 \mathrm{~h}$ at $30{ }^{\circ} \mathrm{C}, 40{ }^{\circ} \mathrm{C}, 42.5{ }^{\circ} \mathrm{C}, 45{ }^{\circ} \mathrm{C}$, $50{ }^{\circ} \mathrm{C}, 60{ }^{\circ} \mathrm{C}, 70{ }^{\circ} \mathrm{C}, 75{ }^{\circ} \mathrm{C}$, or $80{ }^{\circ} \mathrm{C}$, after which the phage suspensions were immediately cooled to $4{ }^{\circ} \mathrm{C}$ for activity estimation. To evaluate the stability of the phage at different $\mathrm{pH}$ levels, $\mathrm{RO}$ medium was adjusted to $\mathrm{pH} 1-14$ with sterile $5 \mathrm{M} \mathrm{HCl}$ or $\mathrm{NaOH}$ solution and then filtered through a $0.22-\mu \mathrm{m}$ membrane filter (Millipore, USA). Additionally, $1 \mathrm{~mL}$ of a phage suspension $\left(\sim 10{ }^{7} \mathrm{PFU} / \mathrm{mL}\right)$ prefiltered through a $0.22-\mu \mathrm{m}$ membrane filter was incubated at $30{ }^{\circ} \mathrm{C}$ for $24 \mathrm{~h}$ in $9 \mathrm{~mL}$ $\mathrm{RO}$ medium of different $\mathrm{pHs}$. Phage activity was determined using the double-layer agar method with $\mathrm{RO}$ medium ( $\mathrm{pH} 7.5)$ at $30{ }^{\circ} \mathrm{C}$ and assessed by calculating changes in PFU following exposure to the different temperatures and $\mathrm{pH}$ levels. All assays were performed in triplicate.

\section{Effects of temperature and $\mathrm{pH}$ on infection}

To investigate the effect of temperature on phage infection, $5 \mu \mathrm{L}$ of a phage suspension $\left(\sim 10^{9} \mathrm{PFU} / \mathrm{mL}\right)$ was added dropwise onto double-layer agar plates containing $E$. litoralis DSM 8509 and incubated at $15{ }^{\circ} \mathrm{C}, 20^{\circ} \mathrm{C}, 25^{\circ} \mathrm{C}, 27.5^{\circ} \mathrm{C}$, $30{ }^{\circ} \mathrm{C}, 35^{\circ} \mathrm{C}$, and $40{ }^{\circ} \mathrm{C}$ for 7 days. To investigate the effect of $\mathrm{pH}$ on infection, the $\mathrm{pH}$ of $\mathrm{RO}$ medium was adjusted with $5 \mathrm{M} \mathrm{HCl}(\mathrm{pH} 4-5), 0.2 \mathrm{M} \mathrm{Na}_{2} \mathrm{HPO}_{4} / \mathrm{NaH}_{2} \mathrm{PO}_{4}$ (pH 6-8) or $0.1 \mathrm{M} \mathrm{NaHCO} / \mathrm{Na}_{2} \mathrm{CO}_{3}(\mathrm{pH} 9-11)$; after autoclaving, the $\mathrm{pH}$ was checked with $\mathrm{pH}$ test paper and readjusted if necessary. Next, $5 \mu \mathrm{L}$ of a phage suspension $\left(\sim 10{ }^{9} \mathrm{PFU} / \mathrm{mL}\right)$ was added dropwise onto double-layer agar plates inoculated with host cells at different $\mathrm{pH}$ values. The plates were incubated at $30{ }^{\circ} \mathrm{C}$ for up to 7 days. All assays were performed in triplicate.

\section{Lysogenic/lytic assays}

To investigate whether the phage can integrate onto the genome of its host, $10 \mu \mathrm{L}$ of a phage suspension $\left(\sim 10^{9}\right.$ $\mathrm{PFU} / \mathrm{mL}$ ) was added dropwise onto double-layer agar plates inoculated with E. litoralis DSM 8509; the center portion within the plaques was carefully pipetted out and inoculated onto a new plate. After two rounds of isolation and purification, 40 randomly selected bacterial colonies were chosen for colony polymerase chain reaction (PCR) using two pairs of primers, designed according to phage genome annotation, targeting ORF 91 (Major capsid protein) (forward primer 5' -GCTGAC CACCAAGCAGATGA - 3', reverse primer $5^{\prime}$ CGGAACGAGGCTATCCCAC - 3', 521 bp) and ORF 100 (Terminase) (forward primer 5' - TCATGTGGCAG GCTTGGG - 3', reverse primer 5' - GGGTCGGTCC AGTCTTTCG - 3', 549 bp).

Phage DNA extraction, sequencing, and genomic analysis Using the same sample preparation utilized for TEM analysis, $1 \mathrm{~mL}$ of a phage suspension was purified by $\mathrm{CsCl}$ density-gradient centrifugation, followed by dialysis. To remove free DNA and RNA, the sample was then digested at $37{ }^{\circ} \mathrm{C}$ for $1 \mathrm{~h}$ with DNase I and RNase A (Takara) at final concentrations of $1 \mu \mathrm{g} / \mathrm{mL}$. The solution was incubated with proteinase $\mathrm{K}$ and sodium dodecyl sulfate at final concentrations of $100 \mu \mathrm{g} / \mathrm{mL}$ and $1 \%(w / v)$, respectively, at $55^{\circ} \mathrm{C}$ for $2 \mathrm{~h}$. After incubation, the solution was extracted twice with phenol:chloroform:isoamyl alcohol (25:24:1) and once with chloroform:isoamyl alcohol (24:1), after which the solutions were precipitated with sodium acetate and precooled ethanol at final concentrations of $1 / 10$ and $1 / 1(v / v)$, respectively. After overnight incubation at $-20{ }^{\circ} \mathrm{C}$, DNA was collected by centrifugation and successively washed twice with precooled $70 \%$ and $100 \%$ ethanol. The genomic DNA of vB_EliS-R6L was sequenced using the Illumina Miseq platform to generate $2 \times 251 \mathrm{bp}$ paired-end reads. The reads were assembled using CLC Genomics Workbench software $(18,777 \times$ coverage $)$.

\section{Genomic and bioinformatic analyses}

The GeneMarkS online server (http://exon.gatech.edu/ Genemark/genemarks.cgi), Glimmer 3.0 (http://ccb.jhu.e $\mathrm{du} /$ software/glimmer/index.shtml), and the ORF Finder online server (https://www.ncbi.nlm.nih.gov/orffinder/) were used to identify putative open reading frames (ORFs). Genes were annotated using BLAST searches against the NCBI non-redundant (nr) protein database, 
with a cut-off of E-value $\leq 10^{-5}$. A temperate and/or lytic lifestyle was predicted using the phage classification toolset (PHACTS) online prediction program (http:// www.phantome.org/PHACTS/index.php). Methylase ORFs were searched using the REBASE ${ }^{\mathrm{R}}$ online program (http://rebase.neb.com/rebase/rebase.html).

The amino acid sequences of endolysin protein (ORF 74), major capsid protein (ORF 91), portal protein (ORF 98), and terminase (ORF 100) from phage vB_EliS-R6L were used to construct neighbor-joining phylogenetic trees with MEGA 6.06 and 200 bootstrap replications. For use in the phylogenetic analysis, the amino acid sequences of these four proteins from closely related phages were retrieved from GenBank.

\section{Genome recruitment}

To explore the geographic distribution of vB_EliS-R6L-like phages, the amino acid sequences of the phage ORFs were employed as queries to search against metagenomic databases of the Jiulong River Estuary (JRE), Xiamen, China [28], the Pacific Ocean Virome (POV) and Global Ocean Survey (GOS) (http://data.imicrobe.us/) using tBLASTn at a cut-off of E-value $\leq 10^{-5}$, an alignment value $\geq 30$ and a score value $\geq 40$. The count abundance of each read was normalized by dividing by the number of total reads in the database and the size of the gene product [20].

\section{Nucleotide sequence accession number}

The genome sequence of phage vB_EliS-R6L was deposited in the GenBank database under accession number KY006853.

\section{Results and discussion}

\section{Phage isolation and basic characterization}

To the best of our knowledge, vB_EliS-R6L is the first phage isolated from the ecologically important marine bacteria of the genus Erythrobacter. vB_EliS-R6L forms small, clear, round (1-4 mm diameter) plaques on a bacterial lawn (Fig. 1). After treatment with different concentrations of chloroform (i.e., $1 \%, 10 \%$, and $100 \%(v / v))$, the phage showed survival rates of $94.7 \pm 4.9 \%$, $83.1 \pm 2.5 \%$, and $81.9 \pm 1.9 \%$, respectively, indicating that vB_EliS-R6L may not sensitive to chloroform or contain lipids. TEM micrographs revealed that it belongs to the siphovirus family, with an icosahedral capsid $75.9 \pm 2.2 \mathrm{~nm}$ in diameter and a characteristically long tail of $165.6 \pm 2.3 \mathrm{~nm}$ (Fig. 1).

Of all the strains tested, phage vB_EliS-R6L could only infect E. litoralis DSM 8509 and E. longus DSM 6997, the only strains for each species that could be obtained from public culture collections. Of the commonly isolated three-tailed phage families (Myoviridae, Siphoviridae, and Podoviridae), Myoviridae phages have a broader host range than species of the other two

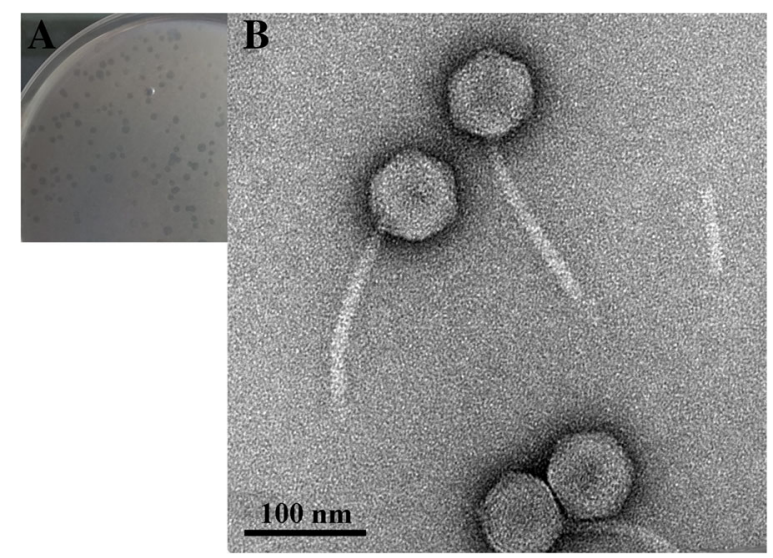

Fig. 1 Plaque (a) and TEM (b) images of Erythrobacter litoralis DSM 8509 phage vB_EliS-R6L particles. The scale bar (b) equals $100 \mathrm{~nm}$

families. Therefore, it was not unexpected that a narrow host range was observed for phage vB_EliS-R6L. Based on whole-genome comparison, Zheng et al. (2016) reported that Erythrobacter strains cluster into three groups, with strains DSM 8509, DSM 6997, and JL 475 belonging to the same group. These three strains share high 16S rRNA gene identity (>97\%) but can be discriminated by average nucleotide identity analysis [11]. Integrative and conjugative element analysis showed that DSM 8509 and DSM 6997 cluster closely together and away from JL 475, suggesting asynchronous evolution. This may account for the ability of phage vB_EliS-R6L to infect DSM 8509 and 6997 but not JL 475. In addition, previous studies have suggested that the number of tRNAs can be positively correlated with host range due to compensation for different codon usage patterns in host bacteria [29]. No tRNAs were identified in the phage vB_EliS-R6L genome using tRNAscan-SE (1.3.1) software [30], which may also account for its relatively narrow host range. In lysogenic/lytic assays, $17.5 \%$ (7/40) of bacterial isolates from the center portion of plaques showed positive PCR amplification using primers specific for phage ORFs. This finding suggests that vB_EliS-R6L may integrate into its host cell and possibly enter into a lysogenic life cycle, which is consistent with our bioinformatic analysis (see below).

According to one-step growth curve experiments, the eclipse and latent periods of phage infection occurred at $2 \mathrm{~h} 40 \mathrm{~min}$ and $3 \mathrm{~h}$ post-infection, respectively (Fig. 2). The burst size was $\sim 86 \mathrm{PFU} /$ cell, similar to the latent period and burst size of most phages infecting Roseobacter species, ranging from $<1-6 \mathrm{~h}$ and $27-1500 \mathrm{PFU} / \mathrm{cell}$, respectively [23, 31-33]. Stability assessment showed that over $60 \%$ of vB_EliS-R6L phage remained active at temperatures up to $50{ }^{\circ} \mathrm{C}(2 \mathrm{~h}$ treatment $)$ and that $<1 \%$ remained active at temperatures $>70{ }^{\circ} \mathrm{C}$ (Fig. 3). In addition, the phage survival rate was greater than $77 \%$ 

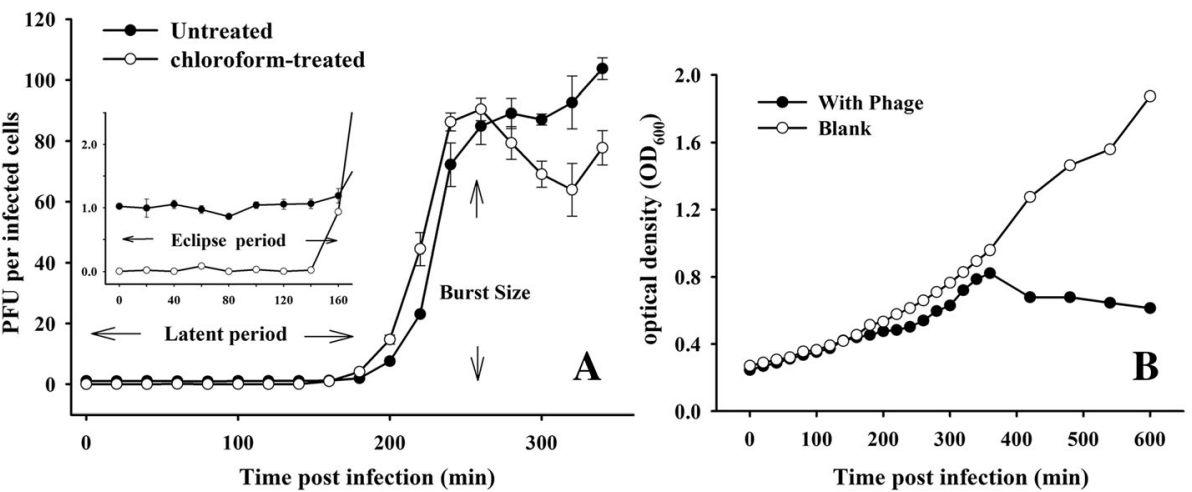

Fig. 2 One-step growth curve analysis of Erythrobacter litoralis phage vB_EliS-R6L. (a) the Plaque forming Unints (PFUs) of the phage and (b) the optical density $\left(\mathrm{OD}_{600}\right)$ of Erythrobacter litoralis DSM 8509. Open circles (a), chloroform-treated samples; closed circles (a), non-chloroform-treated samples. Open circles (b), without phage-inoculated samples; closed circles (b), phage-inoculated samples. OD, optical density

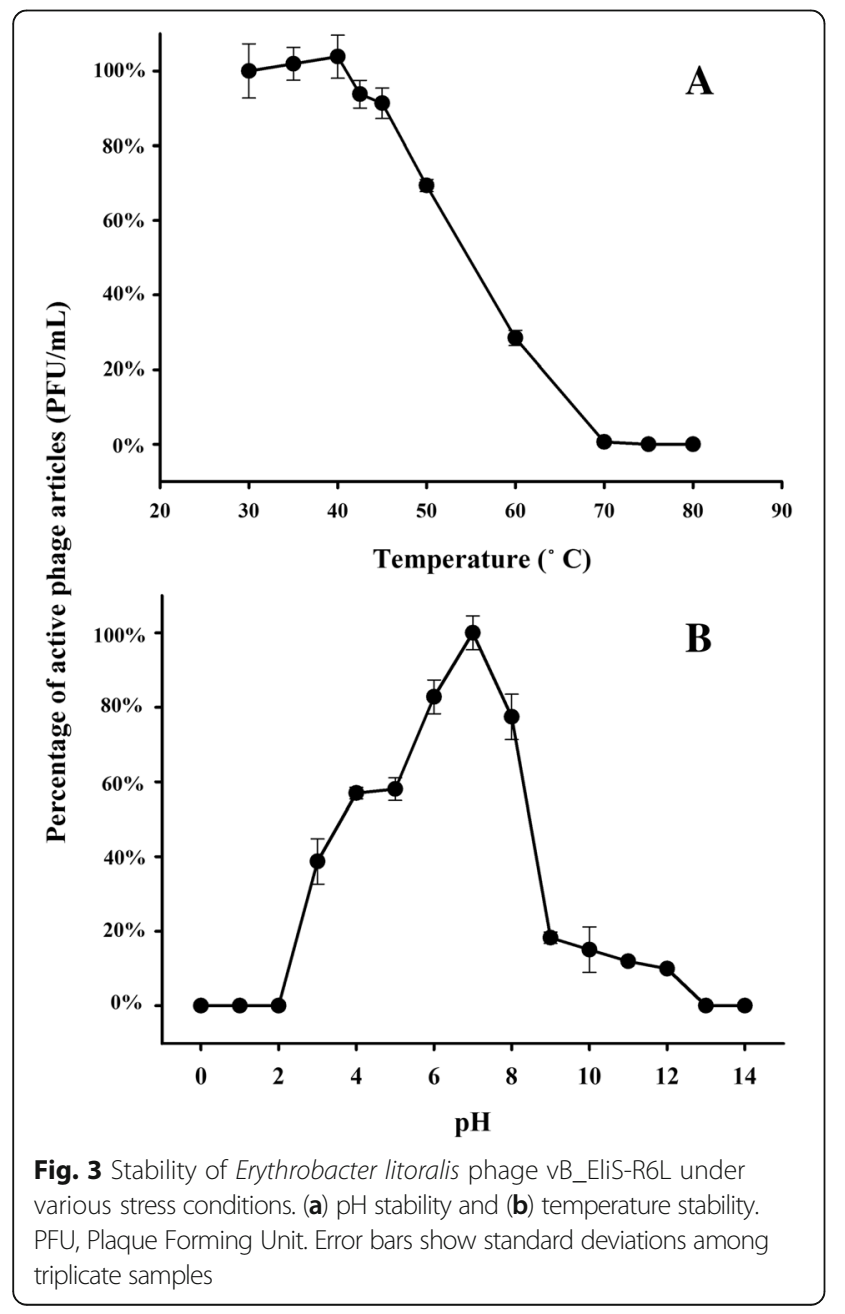

after $24 \mathrm{~h}$ at $\mathrm{pH}$ 6, 7, or 8 (Fig. 3). Although vB_EliS-R6L retained some activity after $24 \mathrm{~h}$ at $\mathrm{pH} 3(39 \%)$ and $\mathrm{pH} 12(10 \%)$, activity was lost below $\mathrm{pH} 2$ or above $\mathrm{pH}$ 13. An infection condition test showed that phage vB_EliS-R6L could infect E. litoralis DSM 8509 and form clear plaques on plates within 2 days at $25{ }^{\circ} \mathrm{C} \sim 35{ }^{\circ} \mathrm{C}$. Visible plaques appeared on plates after 4 days at $15^{\circ} \mathrm{C}$ and $20^{\circ} \mathrm{C}$, whereas no clear plaques were visible at $40{ }^{\circ} \mathrm{C}$ after 7 days of incubation. In addition, plaques were observed in the infection test within a $\mathrm{pH}$ range of 7-10. These data showed phage vB_EliS-R6L particles to be stable, with broad temperature and $\mathrm{pH}$ tolerance compared to most isolated phages [34], characteristics that might offer more survival opportunities in the diverse marine environment. However, phage vB_EliS-R6L was only able to successfully proliferate within a relatively narrow range of conditions (i.e., $<40{ }^{\circ} \mathrm{C}, \mathrm{pH} 7-10$ ). Unsuccessful infection might be a consequence of thermal/chemical alterations to the phage structure or host receptors [35, 36], and further investigation is needed.

\section{Genomic analysis of phage vB_EliS-R6L}

The complete dsDNA genome of phage vB_EliS-R6L is 65,675 bp in size (GenBank accession no. KY006853). The overall $\mathrm{G}+\mathrm{C}$ content is $66.5 \%$, similar to that of its host (i.e., 65.2\%, GenBank accession no. NZ_CP017057). A total of 108 ORFs were identified (Table 2), and identity of the predicted coding sequences with sequences available in GenBank is low (26-77\% at the amino acid level). Homologous sequences in the NCBI non-redundant protein database were found for 58 gene products; however, only 29 had predicted functions (Table 2), 19 of which have been assigned to known functional domain categories. In total, 27 ORFs are homologous with previously identified bacteriophage genes, and 15 are homologs of proteins from siphophage-infecting Alphaproteobacteria. 
Table 2 Erythrobacter litoralis DSM 8509 phage vB_EliS-R6L genome annotations (KY006853)

\begin{tabular}{|c|c|c|c|c|c|c|c|c|c|c|}
\hline Gene & Strand & $\begin{array}{l}\text { Start } \\
\text { (bp) }\end{array}$ & $\begin{array}{l}\text { Stop } \\
\text { (bp) }\end{array}$ & $\begin{array}{l}\text { Residue } \\
\text { length } \\
\text { (nn) }\end{array}$ & $\begin{array}{l}\text { Residue } \\
\text { length } \\
\text { (aa) }\end{array}$ & Putative function/feature & $\begin{array}{l}\text { Best matched } \\
\text { evidence } \\
\text { or organism }\end{array}$ & $\begin{array}{l}\text { Homolog } \\
\text { Accession } \\
\text { Num. }\end{array}$ & $\begin{array}{l}\% \\
\text { ld }\end{array}$ & $\begin{array}{l}\text { BlastP } \\
\text { E-Value }\end{array}$ \\
\hline 1 & - & $<3$ & 2423 & 2421 & 830 & DNA modification methylase & $\begin{array}{l}\text { uncultured } \\
\text { Mediterranean } \\
\text { phage uvMED }\end{array}$ & BAQ92410 & 55 & $2.00 \mathrm{E}-47$ \\
\hline 2 & - & 2420 & 2875 & 456 & 151 & $\begin{array}{l}\text { hypothetical protein } \\
\text { (DNA polymerase III } \\
\text { beta clamp) }\end{array}$ & $\begin{array}{l}\text { Methylobacterium } \\
\text { sp. ARG-1 } \\
\text { (Caulobacter } \\
\text { phage Sansa) }\end{array}$ & $\begin{array}{l}\text { WP_050734237 } \\
\text { (AKU43506) }\end{array}$ & $\begin{array}{l}49 \\
(27)\end{array}$ & $\begin{array}{l}\text { 7.00E-11 } \\
(3.00 \mathrm{E}-04)\end{array}$ \\
\hline 3 & - & 2883 & 3239 & 357 & 118 & hypothetical protein & None & $\mathrm{n} / \mathrm{a}$ & $\mathrm{n} / \mathrm{a}$ & $\mathrm{n} / \mathrm{a}$ \\
\hline 4 & - & 3286 & 3456 & 171 & 56 & hypothetical protein & None & $\mathrm{n} / \mathrm{a}$ & $\mathrm{n} / \mathrm{a}$ & $\mathrm{n} / \mathrm{a}$ \\
\hline 5 & - & 3453 & 3614 & 162 & 53 & hypothetical protein & None & $\mathrm{n} / \mathrm{a}$ & $\mathrm{n} / \mathrm{a}$ & $\mathrm{n} / \mathrm{a}$ \\
\hline 6 & - & 3601 & 3813 & 213 & 70 & hypothetical protein & None & $\mathrm{n} / \mathrm{a}$ & $\mathrm{n} / \mathrm{a}$ & $\mathrm{n} / \mathrm{a}$ \\
\hline 7 & - & 3810 & 4853 & 1044 & 347 & $\begin{array}{l}\text { phosphoadenosine } \\
\text { phosphosulfate } \\
\text { reductase }\end{array}$ & $\begin{array}{l}\text { Sphingomonas } \\
\text { sp. LH128 }\end{array}$ & WP_008827527 & 49 & $3.00 \mathrm{E}-85$ \\
\hline 8 & - & 4835 & 5023 & 189 & 62 & hypothetical protein & None & $\mathrm{n} / \mathrm{a}$ & $\mathrm{n} / \mathrm{a}$ & $\mathrm{n} / \mathrm{a}$ \\
\hline 9 & - & 5020 & 5628 & 609 & 202 & molecular chaperone & $\begin{array}{l}\text { Caulobacter phage } \\
\text { Sansa }\end{array}$ & AKU43478 & 41 & $5.00 \mathrm{E}-42$ \\
\hline 10 & - & 5674 & 6315 & 642 & 213 & hypothetical protein & $\begin{array}{l}\text { Pseudomonas } \\
\text { oryzihabitans }\end{array}$ & WP_044342705 & 55 & $2.00 \mathrm{E}-63$ \\
\hline 11 & - & 6322 & 6558 & 237 & 78 & hypothetical protein & None & $\mathrm{n} / \mathrm{a}$ & $\mathrm{n} / \mathrm{a}$ & $\mathrm{n} / \mathrm{a}$ \\
\hline 12 & - & 6537 & 6791 & 255 & 84 & hypothetical protein & $\begin{array}{l}\text { Sphingomonas sp. } \\
\text { Ant } \mathrm{H} 11\end{array}$ & WP_052192475 & 52 & $3.00 \mathrm{E}-23$ \\
\hline 13 & - & 6791 & 7174 & 384 & 127 & hypothetical protein & $\begin{array}{l}\text { uncultured } \\
\text { Mediterranean } \\
\text { phage uvMED } \\
\text { (Caulobacter phage } \\
\text { Sansa) }\end{array}$ & $\begin{array}{l}\text { BAR28076 } \\
\text { (AKU43468) }\end{array}$ & $\begin{array}{l}39 \\
(27)\end{array}$ & $\begin{array}{l}5.00 \mathrm{E}-08 \\
(7.00 \mathrm{E}-04)\end{array}$ \\
\hline 14 & - & 7171 & 7473 & 303 & 100 & hypothetical protein & None & $\mathrm{n} / \mathrm{a}$ & $\mathrm{n} / \mathrm{a}$ & $\mathrm{n} / \mathrm{a}$ \\
\hline 15 & - & 7473 & 7904 & 432 & 143 & hypothetical protein & None & $\mathrm{n} / \mathrm{a}$ & $\mathrm{n} / \mathrm{a}$ & $\mathrm{n} / \mathrm{a}$ \\
\hline 16 & - & 7901 & 8050 & 150 & 49 & hypothetical protein & None & $\mathrm{n} / \mathrm{a}$ & $\mathrm{n} / \mathrm{a}$ & $\mathrm{n} / \mathrm{a}$ \\
\hline 17 & - & 8047 & 8397 & 351 & 116 & hypothetical protein & None & $\mathrm{n} / \mathrm{a}$ & $\mathrm{n} / \mathrm{a}$ & $\mathrm{n} / \mathrm{a}$ \\
\hline 18 & - & 8394 & 8933 & 540 & 179 & hypothetical protein & None & $\mathrm{n} / \mathrm{a}$ & $\mathrm{n} / \mathrm{a}$ & $\mathrm{n} / \mathrm{a}$ \\
\hline 19 & - & 8933 & 9061 & 129 & 42 & hypothetical protein & None & $\mathrm{n} / \mathrm{a}$ & $\mathrm{n} / \mathrm{a}$ & $\mathrm{n} / \mathrm{a}$ \\
\hline 20 & - & 9061 & 9198 & 138 & 45 & hypothetical protein & None & $\mathrm{n} / \mathrm{a}$ & $\mathrm{n} / \mathrm{a}$ & $\mathrm{n} / \mathrm{a}$ \\
\hline 21 & - & 9195 & 9422 & 228 & 75 & hypothetical protein & None & $\mathrm{n} / \mathrm{a}$ & $\mathrm{n} / \mathrm{a}$ & $\mathrm{n} / \mathrm{a}$ \\
\hline 22 & - & 9419 & 9679 & 261 & 86 & $\begin{array}{l}\text { hypothetical protein } \\
\text { P106B_62 }\end{array}$ & $\begin{array}{l}\text { Rhizobium phage } \\
\text { vB_RglS_P106B }\end{array}$ & YP_009005988 & 47 & $2.00 \mathrm{E}-08$ \\
\hline 23 & - & 9733 & 10,005 & 273 & 90 & hypothetical protein & None & $\mathrm{n} / \mathrm{a}$ & $\mathrm{n} / \mathrm{a}$ & $n / a$ \\
\hline 24 & - & 10,005 & 10,118 & 114 & 37 & hypothetical protein & $\begin{array}{l}\text { None } \\
\text { (Caulobacter } \\
\text { phage Sansa) }\end{array}$ & n/a (AKU43430) & $\begin{array}{l}\mathrm{n} / \mathrm{a} \\
(27)\end{array}$ & $\begin{array}{l}\mathrm{n} / \mathrm{a} \\
(2.00 \mathrm{E}-06)\end{array}$ \\
\hline 25 & - & 10,115 & 10,603 & 489 & 162 & hypothetical protein & None & $\mathrm{n} / \mathrm{a}$ & $\mathrm{n} / \mathrm{a}$ & $\mathrm{n} / \mathrm{a}$ \\
\hline 26 & - & 10,596 & 11,546 & 951 & 316 & hypothetical protein & Rhizobium tropici & WP_052227599 & 45 & $1.10 \mathrm{E}-02$ \\
\hline 27 & - & 11,697 & 12,263 & 567 & 188 & hypothetical protein & $\begin{array}{l}\text { Sphingomonas } \\
\text { sp. Y57 }\end{array}$ & WP_053000396 & 41 & $3.00 \mathrm{E}-31$ \\
\hline 28 & - & 12,278 & 12,880 & 603 & 200 & hypothetical protein & $\begin{array}{l}\text { Novosphingobium } \\
\text { sp. ST904 }\end{array}$ & WP_054436273 & 39 & $3.00 \mathrm{E}-23$ \\
\hline 29 & - & 12,867 & 13,688 & 822 & 273 & hypothetical protein & $\begin{array}{l}\text { Erythrobacter sp. } \\
\text { SG61-1 L }\end{array}$ & WP_054529722 & 40 & $3.00 \mathrm{E}-10$ \\
\hline 30 & - & 13,961 & 14,176 & 216 & 71 & hypothetical protein & None & $\mathrm{n} / \mathrm{a}$ & $\mathrm{n} / \mathrm{a}$ & $\mathrm{n} / \mathrm{a}$ \\
\hline
\end{tabular}


Table 2 Erythrobacter litoralis DSM 8509 phage vB_EliS-R6L genome annotations (KY006853) (Continued)

\begin{tabular}{|c|c|c|c|c|c|c|c|c|c|c|}
\hline 31 & - & 14,173 & 14,859 & 687 & 228 & hypothetical protein & $\begin{array}{l}\text { Lactobacillus } \\
\text { phage LL-H }\end{array}$ & YP_001285924 & 43 & $1.00 \mathrm{E}-18$ \\
\hline 32 & - & 14,856 & 15,137 & 282 & 93 & acyl carrier protein & $\begin{array}{l}\text { Ruminococcus } \\
\text { albus }\end{array}$ & WP_037276568 & 44 & $6.00 \mathrm{E}-13$ \\
\hline 33 & - & 15,195 & 15,818 & 624 & 207 & hypothetical protein & $\begin{array}{l}\text { Sphingomonas } \\
\text { wittichii }\end{array}$ & WP_016745765 & 29 & $6.00 \mathrm{E}-10$ \\
\hline 34 & - & 15,808 & 16,488 & 681 & 226 & methyltransferase & $\begin{array}{l}\text { Caulobacter phage } \\
\text { Sansa }\end{array}$ & AKU43482 & 31 & $2.00 \mathrm{E}-08$ \\
\hline 35 & - & 16,488 & 16,703 & 216 & 71 & hypothetical protein & None & $\mathrm{n} / \mathrm{a}$ & $\mathrm{n} / \mathrm{a}$ & $\mathrm{n} / \mathrm{a}$ \\
\hline 36 & + & 16,834 & 17,106 & 273 & 90 & hypothetical protein & None & $\mathrm{n} / \mathrm{a}$ & $\mathrm{n} / \mathrm{a}$ & $\mathrm{n} / \mathrm{a}$ \\
\hline 37 & + & 17,106 & 17,384 & 279 & 92 & hypothetical protein & None & $\mathrm{n} / \mathrm{a}$ & $\mathrm{n} / \mathrm{a}$ & $\mathrm{n} / \mathrm{a}$ \\
\hline 38 & + & 17,381 & 17,662 & 282 & 93 & hypothetical protein & None & $\mathrm{n} / \mathrm{a}$ & $\mathrm{n} / \mathrm{a}$ & $\mathrm{n} / \mathrm{a}$ \\
\hline 39 & + & 17,664 & 17,909 & 246 & 81 & hypothetical protein & None & $\mathrm{n} / \mathrm{a}$ & $\mathrm{n} / \mathrm{a}$ & $\mathrm{n} / \mathrm{a}$ \\
\hline 40 & + & 17,986 & 18,774 & 789 & 262 & $\begin{array}{l}\text { type I restriction-modification } \\
\text { system methyltransferase } \\
\text { subunit-like protein }\end{array}$ & $\begin{array}{l}\text { Methylobacterium } \\
\text { nodulans } \\
\text { ORS } 2060\end{array}$ & YP_009126070 & 41 & $2.71 E-44$ \\
\hline 41 & + & 18,774 & 20,180 & 1407 & 468 & $\begin{array}{l}\text { nucleoside triphosphate } \\
\text { hydrolase }\end{array}$ & $\begin{array}{l}\text { Caulobacter phage } \\
\text { Sansa }\end{array}$ & AKU43472 & 37 & $1.00 \mathrm{E}-59$ \\
\hline 42 & + & 20,177 & 20,440 & 264 & 87 & hypothetical protein & $\begin{array}{l}\text { Sphingomonas sp. } \\
\text { BHC-A }\end{array}$ & WP_025772726 & 51 & $1.00 \mathrm{E}-13$ \\
\hline 43 & + & 20,437 & 20,730 & 294 & 97 & hypothetical protein & None & $\mathrm{n} / \mathrm{a}$ & $\mathrm{n} / \mathrm{a}$ & $\mathrm{n} / \mathrm{a}$ \\
\hline 44 & + & 20,723 & 20,983 & 261 & 86 & hypothetical protein & None & $\mathrm{n} / \mathrm{a}$ & $\mathrm{n} / \mathrm{a}$ & $\mathrm{n} / \mathrm{a}$ \\
\hline 45 & + & 20,980 & 22,629 & 1650 & 549 & $\begin{array}{l}\text { nucleic acid-binding } \\
\text { protein }\end{array}$ & $\begin{array}{l}\text { Caulobacter phage } \\
\text { Sansa }\end{array}$ & AKU43470 & 30 & $2.00 \mathrm{E}-12$ \\
\hline 46 & + & 22,626 & 23,351 & 726 & 241 & exonuclease & $\begin{array}{l}\text { Sphingobium baderi } \\
\text { LL03 (Caulobacter } \\
\text { phage Sansa) }\end{array}$ & $\begin{array}{l}\text { KMS62764 } \\
\text { (AKU43467) }\end{array}$ & $\begin{array}{l}46 \\
(35)\end{array}$ & $\begin{array}{l}8.00 \mathrm{E}-64 \\
(1.00 \mathrm{E}-22)\end{array}$ \\
\hline 47 & + & 23,341 & 24,513 & 1173 & 390 & ERF family protein & $\begin{array}{l}\text { Dunaliella viridis } \\
\text { virus SI2 }\end{array}$ & YP_009021005 & 31 & 1.00E-19 \\
\hline 48 & + & 24,513 & 24,677 & 165 & 54 & hypothetical protein & None & $\mathrm{n} / \mathrm{a}$ & $\mathrm{n} / \mathrm{a}$ & $\mathrm{n} / \mathrm{a}$ \\
\hline 49 & + & 24,677 & 25,180 & 504 & 167 & $\begin{array}{l}\text { single-stranded } \\
\text { DNA-binding protein }\end{array}$ & $\begin{array}{l}\text { Citromicrobium } \\
\text { (Caulobacter phage } \\
\text { Sansa) }\end{array}$ & $\begin{array}{l}\text { WP_010236565 } \\
\text { (AKU43479) }\end{array}$ & $\begin{array}{l}63 \\
(52)\end{array}$ & $\begin{array}{l}2.00 \mathrm{E}-56 \\
(1.00 \mathrm{E}-52)\end{array}$ \\
\hline 50 & + & 25,192 & 26,049 & 858 & 285 & $\begin{array}{l}\text { phage Gp37Gp68 } \\
\text { (ssDNA-annealing protein) }\end{array}$ & $\begin{array}{l}\text { Sphingomonas sp. } \\
\text { Y57 (Caulobacter } \\
\text { phage Sansa) }\end{array}$ & $\begin{array}{l}\text { WP_047169428 } \\
\text { (AKU43469) }\end{array}$ & $\begin{array}{l}52 \\
(30)\end{array}$ & $\begin{array}{l}\text { 3.00E-89 } \\
(9.00 E-05)\end{array}$ \\
\hline 51 & + & 26,046 & 26,573 & 528 & 175 & hypothetical protein & None & $\mathrm{n} / \mathrm{a}$ & $\mathrm{n} / \mathrm{a}$ & $\mathrm{n} / \mathrm{a}$ \\
\hline 52 & + & 26,598 & 27,239 & 642 & 213 & hypothetical protein & $\begin{array}{l}\text { None (Caulobacter } \\
\text { phage Sansa) }\end{array}$ & n/a (AKU43520) & $\begin{array}{l}n / a \\
(23)\end{array}$ & $\begin{array}{l}\mathrm{n} / \mathrm{a} \\
(3.00 \mathrm{E}-04)\end{array}$ \\
\hline 53 & + & 27,232 & 27,639 & 408 & 135 & hypothetical protein & $\begin{array}{l}\text { Sphingobium } \\
\text { chungbukense }\end{array}$ & WP_046763480 & 43 & $7.00 \mathrm{E}-15$ \\
\hline 54 & - & 27,873 & 28,238 & 366 & 121 & hypothetical protein & $\begin{array}{l}\text { Pseudomonas } \\
\text { aeruginosa }\end{array}$ & WP_052157666 & 48 & $2.00 \mathrm{E}-11$ \\
\hline 55 & + & 28,309 & 28,692 & 384 & 127 & $\begin{array}{l}\text { cytosine-specific } \\
\text { methyltransferase }\end{array}$ & $\begin{array}{l}\text { Ralstonia solanacearum } \\
\text { GMI1000 }\end{array}$ & NP_518991 & 48 & $7.98 \mathrm{E}-23$ \\
\hline 56 & + & 28,730 & 28,918 & 189 & 62 & hypothetical protein & None & $\mathrm{n} / \mathrm{a}$ & $\mathrm{n} / \mathrm{a}$ & $\mathrm{n} / \mathrm{a}$ \\
\hline 57 & + & 28,918 & 29,508 & 591 & 196 & hypothetical protein & None & $\mathrm{n} / \mathrm{a}$ & $\mathrm{n} / \mathrm{a}$ & $\mathrm{n} / \mathrm{a}$ \\
\hline 58 & + & 29,612 & 30,007 & 396 & 131 & hypothetical protein & None & $\mathrm{n} / \mathrm{a}$ & $\mathrm{n} / \mathrm{a}$ & $\mathrm{n} / \mathrm{a}$ \\
\hline 59 & + & 30,092 & 30,574 & 483 & 160 & hypothetical protein & None & $\mathrm{n} / \mathrm{a}$ & $\mathrm{n} / \mathrm{a}$ & $\mathrm{n} / \mathrm{a}$ \\
\hline 60 & + & 30,574 & 30,828 & 255 & 84 & hypothetical protein & None & $\mathrm{n} / \mathrm{a}$ & $\mathrm{n} / \mathrm{a}$ & $\mathrm{n} / \mathrm{a}$ \\
\hline 61 & + & 30,903 & 31,304 & 402 & 133 & $\begin{array}{l}\text { MucR family transcriptional } \\
\text { regulator }\end{array}$ & $\begin{array}{l}\text { Methylobacterium } \\
\text { nodulans }\end{array}$ & WP_012631401 & 55 & $3.00 \mathrm{E}-33$ \\
\hline
\end{tabular}


Table 2 Erythrobacter litoralis DSM 8509 phage vB_EliS-R6L genome annotations (KY006853) (Continued)

\begin{tabular}{|c|c|c|c|c|c|c|c|c|c|c|}
\hline 62 & + & 31,301 & 31,687 & 387 & 128 & hypothetical protein & None & $n / a$ & $\mathrm{n} / \mathrm{a}$ & $\mathrm{n} / \mathrm{a}$ \\
\hline 63 & + & 31,684 & 31,902 & 219 & 72 & hypothetical protein & None & $\mathrm{n} / \mathrm{a}$ & $\mathrm{n} / \mathrm{a}$ & $\mathrm{n} / \mathrm{a}$ \\
\hline 64 & + & 31,893 & 32,033 & 141 & 46 & hypothetical protein & None & $\mathrm{n} / \mathrm{a}$ & $\mathrm{n} / \mathrm{a}$ & $\mathrm{n} / \mathrm{a}$ \\
\hline 65 & + & 32,020 & 32,235 & 216 & 71 & hypothetical protein & None & $\mathrm{n} / \mathrm{a}$ & $\mathrm{n} / \mathrm{a}$ & $\mathrm{n} / \mathrm{a}$ \\
\hline 66 & + & 32,235 & 32,468 & 234 & 77 & hypothetical protein & None & $\mathrm{n} / \mathrm{a}$ & $\mathrm{n} / \mathrm{a}$ & $\mathrm{n} / \mathrm{a}$ \\
\hline 67 & + & 32,465 & 33,223 & 759 & 252 & DNA methylase & $\begin{array}{l}\text { Mycobacterium } \\
\text { phage } \\
\text { Llama }\end{array}$ & AlM51011 & 56 & $2.00 \mathrm{E}-51$ \\
\hline 68 & + & 33,259 & 33,612 & 354 & 117 & hypothetical protein & Vibrio phage VVAW1 & YP_007518376 & 44 & 2.00E-20 \\
\hline 69 & + & 33,662 & 33,958 & 297 & 98 & hypothetical protein & $\begin{array}{l}\text { Burkholderia } \\
\text { vietnamiensis }\end{array}$ & WP_011875349 & 34 & $1.00 \mathrm{E}-05$ \\
\hline 70 & + & 33,955 & 34,455 & 501 & 166 & hypothetical protein & $\begin{array}{l}\text { Novosphingobium } \\
\text { sp. KN65.2 }\end{array}$ & CDO34010 & 41 & 4.00E-22 \\
\hline 71 & - & 34,717 & 34,962 & 246 & 81 & hypothetical protein & $\begin{array}{l}\text { Sphingomonas } \\
\text { sanxanigenens }\end{array}$ & WP_025293719 & 52 & $5.00 \mathrm{E}-22$ \\
\hline 72 & - & 35,015 & 35,344 & 330 & 109 & hypothetical protein & $\begin{array}{l}\text { Sphingomonas } \\
\text { sanxanigenens }\end{array}$ & WP_025293718 & 55 & $1.00 \mathrm{E}-08$ \\
\hline 73 & - & 35,316 & 35,633 & 318 & 105 & hypothetical protein & None & $\mathrm{n} / \mathrm{a}$ & $\mathrm{n} / \mathrm{a}$ & $\mathrm{n} / \mathrm{a}$ \\
\hline 74 & - & 35,630 & 36,505 & 876 & 291 & endolysin & $\begin{array}{l}\text { Caulobacter phage } \\
\text { Sansa }\end{array}$ & AKU43454 & 50 & 2.00E-39 \\
\hline 75 & - & 36,552 & 36,776 & 225 & 74 & hypothetical protein & $\begin{array}{l}\text { Sphingomonas } \\
\text { sp. ATCC } 31555\end{array}$ & WP_019371220 & 68 & 2.00E-12 \\
\hline 76 & - & 36,935 & 37,528 & 594 & 197 & hypothetical protein & $\begin{array}{l}\text { Sphingomonas } \\
\text { sp. ATCC } 31555\end{array}$ & WP_019371221 & 44 & $2.00 \mathrm{E}-34$ \\
\hline 77 & - & 37,589 & 39,856 & 2268 & 755 & $\begin{array}{l}\text { D-alanyl-D-alanine } \\
\text { carboxypeptidase }\end{array}$ & $\begin{array}{l}\text { Methyloceanibacter } \\
\text { caenitepidi }\end{array}$ & BAQ15659 & 33 & $2.00 \mathrm{E}-25$ \\
\hline 78 & - & 39,853 & 40,308 & 456 & 151 & hypothetical protein & Delftia sp. RIT313 & WP_052155377 & 54 & $2.00 \mathrm{E}-27$ \\
\hline 79 & - & 40,309 & 43,059 & 2751 & 916 & virion structural protein & $\begin{array}{l}\text { Pseudomonas phage } \\
\text { PaMx28 }\end{array}$ & ALH23633 & 44 & $0.00 E+00$ \\
\hline 80 & - & 43,088 & 43,282 & 195 & 64 & tail assembly protein & Burkholderia phage $\mathrm{AH} 2$ & YP_006561132 & 53 & 1.00E-15 \\
\hline 81 & - & 43,279 & 43,509 & 231 & 76 & virion structural protein & $\begin{array}{l}\text { Pseudomonas phage } \\
\text { PaM } 25\end{array}$ & ALH23804 & 77 & $5.00 \mathrm{E}-17$ \\
\hline 82 & - & 43,509 & 44,288 & 780 & 259 & virion structural protein & $\begin{array}{l}\text { Pseudomonas phage } \\
\text { PaMx28 }\end{array}$ & ALH23630 & 48 & 2.00E-72 \\
\hline 83 & - & 44,285 & 45,874 & 1590 & 529 & $\begin{array}{l}\text { tail assembly structural } \\
\text { protein }\end{array}$ & $\begin{array}{l}\text { Pseudomonas phage } \\
\text { MP1412 }\end{array}$ & YP_006561079 & 35 & 1.00E-55 \\
\hline 84 & - & 45,871 & 49,170 & 3300 & 1099 & tail tape-measure protein & $\begin{array}{l}\text { Paracoccus phage } \\
\text { VB_PmaS_IMEP1 }\end{array}$ & YP_009126438 & 51 & $3.00 \mathrm{E}-41$ \\
\hline 85 & - & 49,462 & 49,974 & 513 & 170 & hypothetical protein & $\begin{array}{l}\text { Roseobacter phage } \\
\text { RDJL Phi } 2\end{array}$ & AKQ75858 & 26 & 8.00E-06 \\
\hline 86 & - & 50,038 & 51,579 & 1542 & 513 & major capsid protein & $\begin{array}{l}\text { Roseobacter phage } \\
\text { RDJL Phi } 1\end{array}$ & YP_004421846 & 46 & 3.00E-138 \\
\hline 87 & - & 51,592 & 52,032 & 441 & 146 & phage structural protein & $\begin{array}{l}\text { Roseobacter phage } \\
\text { RDJL Phi } 1\end{array}$ & YP_004421845 & 30 & $9.05 \mathrm{E}-13$ \\
\hline 88 & - & 52,029 & 52,526 & 498 & 165 & virion structural protein & $\begin{array}{l}\text { Pseudomonas phage } \\
\text { PaM } \times 25\end{array}$ & ALH23810 & 34 & $6.00 \mathrm{E}-06$ \\
\hline 89 & - & 52,530 & 53,045 & 516 & 171 & hypothetical protein & None & $\mathrm{n} / \mathrm{a}$ & $\mathrm{n} / \mathrm{a}$ & $\mathrm{n} / \mathrm{a}$ \\
\hline 90 & - & 53,136 & 54,083 & 948 & 315 & hypothetical protein & $\begin{array}{l}\text { Caulobacter phage } \\
\text { Sansa }\end{array}$ & AKU43432 & 61 & $9.00 \mathrm{E}-06$ \\
\hline 91 & - & 54,105 & 55,115 & 1011 & 336 & major capsid protein $\mathrm{E}$ & $\begin{array}{l}\text { Pseudomonas phage } \\
\text { KPP23 (Caulobacter } \\
\text { phage Sansa) }\end{array}$ & $\begin{array}{l}\text { BAO53114 } \\
\text { (AKU43431) }\end{array}$ & $\begin{array}{l}32 \\
(24)\end{array}$ & $\begin{array}{l}8.00 E-39 \\
(9.00 E-12)\end{array}$ \\
\hline 92 & - & 55,201 & 55,578 & 378 & 125 & hypothetical protein & None & $\mathrm{n} / \mathrm{a}$ & $\mathrm{n} / \mathrm{a}$ & $\mathrm{n} / \mathrm{a}$ \\
\hline
\end{tabular}


Table 2 Erythrobacter litoralis DSM 8509 phage vB_EliS-R6L genome annotations (KY006853) (Continued)

\begin{tabular}{|c|c|c|c|c|c|c|c|c|c|c|}
\hline 93 & - & 55,624 & 56,901 & 1278 & 425 & hypothetical protein & $\begin{array}{l}\text { Roseobacter phage } \\
\text { RDJL Phi } 2\end{array}$ & AKQ75851 & 38 & $3.00 \mathrm{E}-21$ \\
\hline 94 & - & 56,891 & 57,370 & 480 & 159 & hypothetical protein & $\begin{array}{l}\text { Roseobacter phage } \\
\text { RDJL Phi } 2\end{array}$ & AKQ75850 & 46 & $1.00 \mathrm{E}-23$ \\
\hline 95 & - & 57,494 & 58,489 & 996 & 331 & $\begin{array}{l}\text { head morphogenesis } \\
\text { protein }\end{array}$ & $\begin{array}{l}\text { Roseobacter phage } \\
\text { RDJL Phi } 2 \\
\text { (Caulobacter phage } \\
\text { Sansa) }\end{array}$ & $\begin{array}{l}\text { AKQ75849 } \\
(\text { AKU43427) }\end{array}$ & $\begin{array}{l}49 \\
(25)\end{array}$ & $\begin{array}{l}\text { 4.00E-80 } \\
(7.00 \mathrm{E}-26)\end{array}$ \\
\hline 96 & - & 58,494 & 58,892 & 399 & 132 & $\begin{array}{l}\text { hypothetical protein } \\
\text { IB60_17100 }\end{array}$ & Brucella abortus LMN1 & KFH18426 & 31 & 5.00E-08 \\
\hline 97 & - & 58,892 & 59,431 & 540 & 179 & $\begin{array}{l}\text { hypothetical protein } \\
\text { (tail protein) }\end{array}$ & $\begin{array}{l}\text { Roseobacter phage } \\
\text { RDJL Phi } 2 \text { (Caulobacter } \\
\text { phage Sansa) }\end{array}$ & $\begin{array}{l}\text { AKQ75847 } \\
\text { (AKU43445) }\end{array}$ & $\begin{array}{l}34 \\
(57)\end{array}$ & $\begin{array}{l}2.00 \mathrm{E}-09 \\
(1.00 \mathrm{E}-03)\end{array}$ \\
\hline 98 & - & 59,431 & 60,993 & 1563 & 520 & portal protein & $\begin{array}{l}\text { Caulobacter phage } \\
\text { Sansa }\end{array}$ & AKU43426 & 25 & 5.00E-18 \\
\hline 99 & - & 61,152 & 61,415 & 264 & 87 & hypothetical protein & None & $\mathrm{n} / \mathrm{a}$ & $\mathrm{n} / \mathrm{a}$ & $\mathrm{n} / \mathrm{a}$ \\
\hline 100 & - & 61,878 & 63,512 & 1635 & 544 & terminase & $\begin{array}{l}\text { Agrobacterium } \\
\text { rhizogenes }\end{array}$ & WP_051696780 & 56 & 3.00E-148 \\
\hline 101 & - & 63,493 & 64,023 & 531 & 176 & hypothetical protein & $\begin{array}{l}\text { Nitratireductor } \\
\text { basaltis }\end{array}$ & WP_051913838 & 30 & $6.00 \mathrm{E}-07$ \\
\hline 102 & + & 64,145 & 64,327 & 183 & 60 & hypothetical protein & None & $\mathrm{n} / \mathrm{a}$ & $\mathrm{n} / \mathrm{a}$ & $\mathrm{n} / \mathrm{a}$ \\
\hline 103 & + & 64,371 & 64,556 & 186 & 61 & hypothetical protein & None & $\mathrm{n} / \mathrm{a}$ & $\mathrm{n} / \mathrm{a}$ & $\mathrm{n} / \mathrm{a}$ \\
\hline 104 & + & 64,553 & 64,687 & 135 & 44 & hypothetical protein & None & $\mathrm{n} / \mathrm{a}$ & $\mathrm{n} / \mathrm{a}$ & $\mathrm{n} / \mathrm{a}$ \\
\hline 105 & + & 64,747 & 65,037 & 291 & 96 & hypothetical protein & None & $\mathrm{n} / \mathrm{a}$ & $\mathrm{n} / \mathrm{a}$ & $\mathrm{n} / \mathrm{a}$ \\
\hline 106 & + & 65,037 & 65,204 & 168 & 55 & hypothetical protein & None & $\mathrm{n} / \mathrm{a}$ & $\mathrm{n} / \mathrm{a}$ & $\mathrm{n} / \mathrm{a}$ \\
\hline 107 & + & 65,233 & 65,520 & 288 & 95 & hypothetical protein & None & $\mathrm{n} / \mathrm{a}$ & $\mathrm{n} / \mathrm{a}$ & $\mathrm{n} / \mathrm{a}$ \\
\hline 108 & + & 65,532 & 65,675 & 144 & 47 & hypothetical protein & None & $n / a$ & $\mathrm{n} / \mathrm{a}$ & $\mathrm{n} / \mathrm{a}$ \\
\hline
\end{tabular}

Overall, as suggested by the low degree of coverage $(<3 \%)$ of the entire genome sequence identified by BLASTn analysis, the vB_EliS-R6L genome is largely unique compared with other published phage genomes.

Eight genes were found to encode proteins related to DNA metabolism. In addition to DNA modification methylase (ORF 1) and DNA methylase (ORF 67), phage vB_EliS-R6L encodes another three methylase proteins, including a methyltransferase (ORF 34), a type I restrictionmodification (R-M) system methyltransferase subunit-like protein (ORF 40), and a cytosine-specific methyltransferase (ORF 55). The identities range from 31 to $56 \%$ (46\% on average). Four of the five ORFs are predicted to contain a single domain, including a CcrM-like domain (ORF 1, with recognition site of GANTC), two SAM methyltransferase domains (COMT-like) (ORF 34 and 40, a versatile enzyme with various target molecules), and a Dam subfamily domain (ORF 67, with a recognition site of GATC). Methyltransferases are ubiquitous in prokaryotic genomes, and these enzymes are often associated with a cognate restriction endonuclease, forming an R-M system that protects bacterial cells from invasion by foreign DNA such as phages. Approximately $20 \%$ of annotated phage genomes encode methylases, and it is proposed that they may help the phage overcome R-M and other phage-targeted resistance systems in the host and prolong the effectiveness of infection [37]. As predicted by REBESE software, one R-M pair was recognized in the genome of E. litoralis DSM 8509 (with the recognition site CCGGAG), and five pairs were found for E. longus DSM 6997 (two of which have recognition sites GGCGCC and CGATCG; the other three have no recognition sites). Those $\mathrm{R}-\mathrm{M}$ recognition sites indicate 37 potential cleavage sites (23 for CCGGAG, 14 for CGATCG) in the genome of phage vB_EliS-R6L. The predicted recognition site GATC of ORF 67 in the phage genome agrees with the R-M sites of DSM 6997, demonstrating the potential to overcome the host R-M system. Previous studies also found that phage T4 encodes a DAM methylase that targets GATC sites, protecting the phage DNA from an R-M system that recognizes this sequence [38]. Based on REBASE searches, 1051 homologs matched with the five methylase proteins, suggesting that R6L-like methylases are widespread, which may enhance infectivity and evasion of the host R-M system. Phage vB_EliS-R6L may represent a good model for exploitation of phage methylases and marine host-phage interactions. Moreover, Dziewit et al. (2014) suggested that methylases may account for differences in the methylation state and 
induce host transcriptional changes that are essential for the phage life cycle [39].

Twelve ORFs are predicted to encode proteins involved in the structure and assembly of virions, nine of which are homologous to genes from Pseudomonas (Gammaproteobacteria) and/or Roseobacter isometric siphophages [21, 40, 41]. A further four conjunctive ORFs with unknown functions also exhibit homology to these phage types. This is consistent with the results of the phylogenetic trees generated using major capsid protein and portal protein amino acid sequences (Fig. 4). However, it is noteworthy that except for these 13 ORFs, no other ORFs of vB_EliS-R6L show a high degree of homology to Pseudomonas or Roseobacter isometric phage sequences. It therefore appears that genes associated with the structural architecture of phage vB_EliSR6L are relatively conserved and may have evolved independently from other genes in the genome. Moreover, the low protein identity predicted between phage vB_EliS-R6L and those homologies $(26-77 \%, 41 \%$ on average), as well as clearly distant phylogenetic relationships (Fig. 4), suggest that phage vB_EliS-R6L exchanged genetic material with those closely related phages prior to a distinct evolutionary path.

One putative endolysin gene (ORF 74) and one molecular chaperone (ORF 9) were identified in the genome of

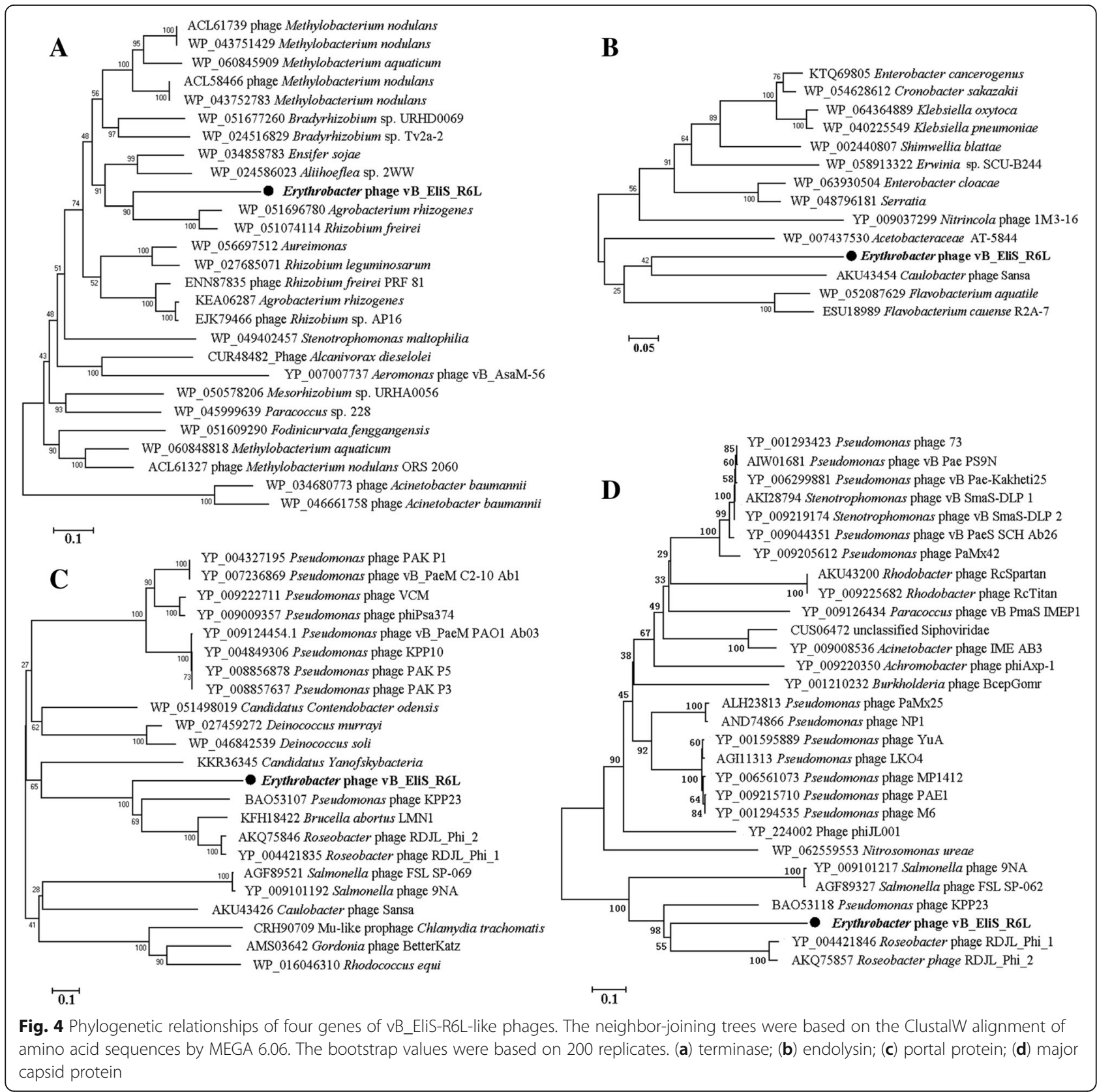


vB_EliS-R6L, sharing 50\% and $41 \%$ amino acid identity, respectively, with the corresponding proteins of the Caulobacter phage Sansa [42]. Most tailed phages achieve lysis via consecutive use two essential proteins, endolysin and holin (which control the length of the infective cycle). Endolysins are phage-encoded enzymes that degrade bacterial peptidoglycan. ORF 74 is predicted to contain one domain: a 176-aa region near the $\mathrm{C}$ terminus that shows homology to proteins of the lysozyme-like superfamily. Although Caulobacter phage Sansa contains a lysis cassette (a holin/antiholin pair and an endolysin) [42], none of the ORFs identified in phage vB_EliS-R6L exhibit homology to holin proteins. This may be the result of the limited number of holin protein sequences in databases [43, 44]. In addition, ORF 9 is predicted to contain one 49-aa domain homologous to chaperone J, which assists in translation.

Three ORFs are predicted to code for an acyl carrier protein (ORF 32), a nucleoside triphosphate hydrolase (ORF 41), and a phosphoadenosine phosphosulfate reductase (ORF 7). The acyl carrier protein in bacteria is responsible for fatty acid biosynthesis, requiring 4'-phosphopantetheine as a covalently attached cofactor. Acyl carrier protein homologs have also been identified in several other phages [45], though their function remains unclear. ORF 41 of phage vB_EliS-R6L is predicted to include a 292-aa Ploop domain of nucleoside triphosphate hydrolases, which hydrolyze the beta-gamma phosphate bond of a bound nucleoside triphosphate, providing energy for viral metabolism. ORF 7 shows $49 \%$ identity to phosphoadenosine phosphosulfate reductases, which have been identified in phages such as Lactobacillus phage AQ113 (GenBank accession no. HE956704) [46], Mycobacterium phage Baka (GenBank accession no. JF937090) [47], and Pseudoalteromonas phage PHS3 (GenBank accession no. KX912252, unpublished). Phosphoadenosine phosphosulfate reductases are thought to be involved in sulfate activation for cysteine biosynthesis. However, no studies have investigated the relationship between the activity of these enzymes and phage metabolism [46, 47].

Based on NCBI BLAST gene annotation results, phage vB_EliS-R6L shares 12 similar ORFs (E-value $<10^{-5}$ ) with the Caulobacter phage Sansa, and another 5 pairs with an E-value $<10^{-3}$ were found [42] (Table 2). The 12 homologous ORFs include 3 involved in DNA metabolism, 3 structural proteins, 1 methylase, 1 endolysin, 1 nucleoside triphosphate hydrolase, 1 molecular chaperone and 2 proteins of unknown function. However, the identities of the 12 pairs are not high (ranging from 23 to $61 \%$; $34 \%$ on average), providing further evidence for the novelty of phage vB_EliS-R6L.
Endolysin protein (ORF 74), major capsid protein (ORF 91), portal protein (ORF 98), and terminase (ORF 100) were chosen for phylogenetic tree construction (Fig. 4). With the exception of the tree based on the terminase protein, in all cases, vB_EliS-R6L clusters with virulent bacteriophages, such as the Caulobacter phage Sansa, roseophages, and Pseudomonas phages. However, the clearly distant phylogenetic relationships with other phages suggest that vB_EliS-R6L is a novel phage. In the terminase-based tree, phage vB_EliS-R6L is located near prophages from Agrobacterium rhizogenes and Rhizobium freirei, agreeing with the BLASTp analysis. In addition, the phage life style predicted by the PHACTS algorithm indicated that it may be a temperate phage. However, no integrase, repressor, or other genes related to the SOS response [48] were identified in the genome of phage vB_EliS-R6L.

\section{Environmental distribution}

Metagenomic analysis indicated that vB_EliS-R6L-like phages are widespread in the examined environmental samples (Fig. 5). Across all metagenomic samples (JRE, POV and GOS), 7138 reads were successfully assigned and detected at rates of $10^{-9}$ to $10^{-7}$ per amino acid pair in the databases. The greatest matches were found in JRE $\left(1.13 \times 10^{-7}\right.$ per pair $)$, from which phage vB_EliSR6L was isolated, followed by POV $\left(1.94 \times 10^{-8}\right.$ per pair $)$ and GOS $\left(1.89 \times 10^{-8}\right.$ per pair $)$ coastal samples. This is in agreement with the general distribution of Erythrobacter in the costal environment [1, 2, 49]. Forty-five ORFs were matched to homologs in the databases. The most relative abundant distribution was for ORF 49 (single-stranded DNA-binding protein, with function of DNA replication/repair, $5.28 \times 10^{-9}$ per pair), ORF 54 (hypothetical protein, $3.05 \times 10^{-9}$ per pair), ORF 32 (acyl carrier protein, $3.18 \times 10^{-9}$ per pair) and ORF 100 (terminase, $5.07 \times 10^{-10}$ per pair). Although the homologs of some ORFs (e.g., 9, 37, 45, 76, 81, 93 and 96) were only found in the JRE virome and/or the POV and GOS coastal samples, the hits for the most matched ORFs covered all three databases. This result suggests that vB_EliS-R6L is a previously unknown phage group that is widely distributed in the marine environment and that it could serve as a good reference for the taxonomic binning of marine viromes in the future.

\section{Conclusion}

Phage vB_EliS-R6L is the first virus identified that can infect marine bacteria belonging to the genus Erythrobacter. The phage has a wide temperature and $\mathrm{pH}$ tolerance. With a $65.7-\mathrm{kb}$ genome encoding 108 putative gene products, phage vB_EliS-R6L is novel among the cultured phage community and is largely different than all other known phages. Phage vB_EliS- 


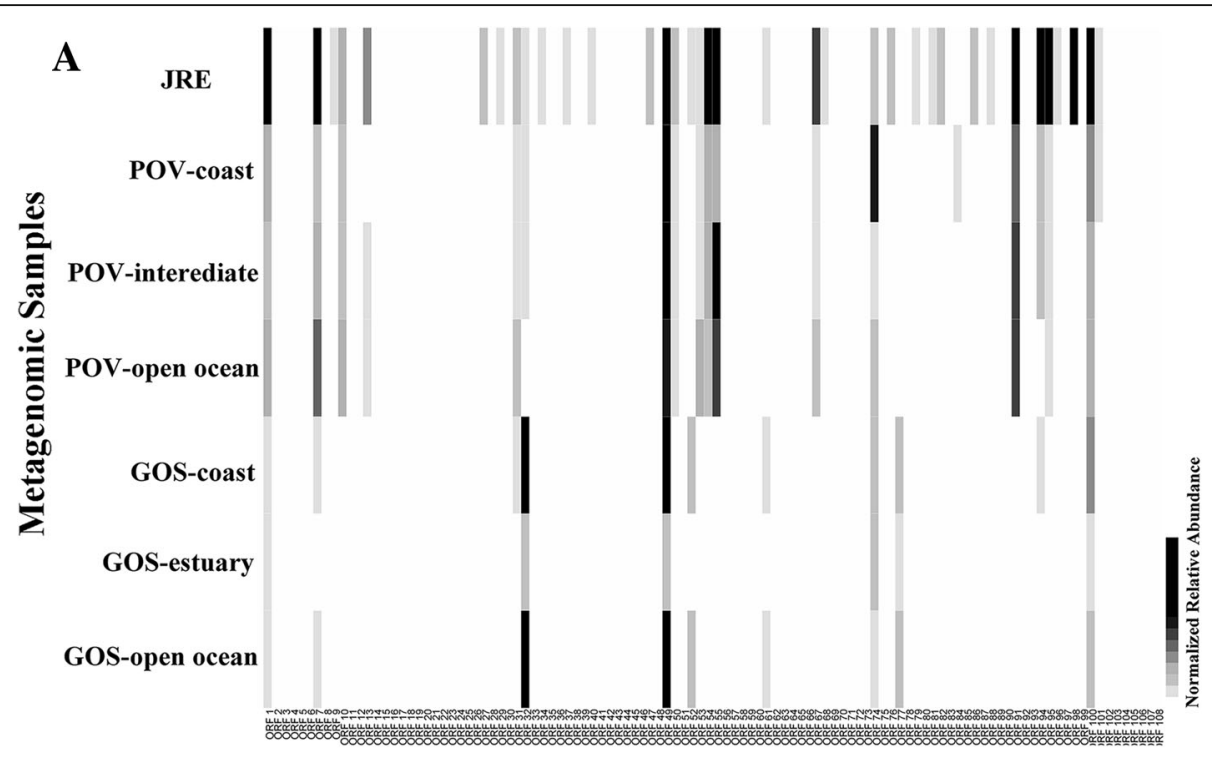

B

ORF numbers of phage vB_EliS-R6L
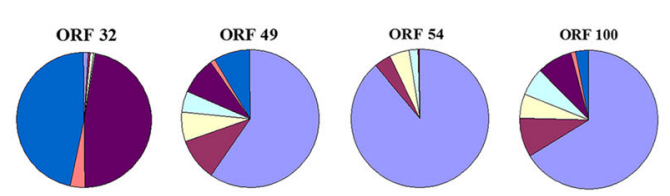

$\square$ JRE

๓ $\mathrm{POV}$-coast

$\square$ POV-interediate

$\square$ POV-open ocean

mos-coast

$\square$ GOS-estuary

GOS-open ocean

Fig. 5 Relative abundance of VB_Elis-R6L -like phage genes in the metagenomes. (a) Heatmap of the normalized relative abundance of VB_EliS-R6L ORFs identified in the Jiulong River Estuary, Xiamen, China (JRE), Pacific Ocean Virome (POV) and Global Ocean Survey (GOS). (b) Normalized relative abundance of ORF 32,49,54 and 100 in the metagenomes

R6L encodes five methylase proteins, suggesting the potential to overcome host resistance systems. Auxiliary metabolic genes in the phage genome were also annotated, such as those coding for an acyl carrier protein and phosphoadenosine phosphosulfate reductases. Metagenomic database queries suggest that vB_EliS-R6L-like phages are widely distributed in the marine environment, especially in coastal waters. Erythrobacter comprises one of the important clades of AAPBs [50,51] and could represent the predominant AAPBs in the upper oceans [7]. Our study provides the basis for in-depth investigation of host-virus interactions and the ecological behavior of marine Erythrobacter.

\section{Abbreviations}

AAPB: Aerobic anoxygenic phototrophic bacteria; SM: Sodium chloridemagnesium sulfate; TEM: Transmission electron microscopy; PFU: Plaque forming unit; EOP: Efficiency of plating; OD: Optical density; PCR: Polymerase chain reaction; ORFs: Open reading frames; R-M: Restriction-modification; JRE: Jiulong River Estuary; POC: Pacific Ocean Virome; GOS: Global Ocean Survey

\section{Acknowledgments}

We greatly thank Yongle Xu and Luming Yao at Xiamen University for their useful suggestions and help.

\section{Funding}

This study was supported by the National Key Basic Research Programs of China (grant NO. 2013CB955700) and the National Natural Science Foundation of China (grant NO. 41522603, 31570172, 91428308).

Availability of data and materials

All data generated or analysed during this study are included in this published article.

\section{Authors' contributions}

$\mathrm{LL}$ and $\mathrm{LC}$ were responsible for samples collection and phage isolation. $\mathrm{LL}$ extracted the viral DNA, sequenced the genome, annotated the genome and carried out the phylogenetic and comparative genomic analyses. $\mathrm{LL}$ drafted the manuscript, and RZ, LC and NJ critically revised the manuscript. $\mathrm{NJ}$ and RZ organized the study. All authors have read and approved final manuscript.

\section{Competing interests}

The authors declare that they have no competing interests.

\section{Consent for publication}

Not applicable.

Ethics approval and consent to participate Not applicable.

\section{Publisher's Note}

Springer Nature remains neutral with regard to jurisdictional claims in published maps and institutional affiliations. 
Received: 26 October 2016 Accepted: 1 June 2017

Published online: 07 June 2017

\section{References}

1. Shiba T, Simidu U. Erythrobacter longus gen. Nov., sp. nov., an aerobic bacterium which contains bacteriochlorophyll a. Int J Syst Bacteriol. 1982;32:211-7.

2. Kolber ZS, VanDover CL, Niederman RA, Falkowski PG. Bacterial photosynthesis in surface waters of the open ocean. Nature. 2000;407:177-9.

3. Yoon J-H, Kang KH, Oh T-K, Park Y-H. Erythrobacter aquimaris sp. nov., isolated from sea water of a tidal flat of the Yellow Sea in Korea. Int J Syst Evol Microbiol. 2004;54:1981-5.

4. Yoon J-H, Kang KH, Yeo S-H, Oh T-K. Erythrobacter luteolus sp. nov., isolated from a tidal flat of the Yellow Sea in Korea. Int J Syst Evol Microbiol. 2005;55:1167-70.

5. Lei X, Zhang H, Chen Y, Li Y, Chen Z, Lai Q, et al. Erythrobacter luteus sp. nov., isolated from mangrove sediment. Int J Syst Evol Microbiol. 2015;65:2472-8.

6. Yurkov W, Beatty JT. Aerobic anoxygenic phototrophic bacteria. Microbiol Mol Biol Rev. 1998;62:695-724.

7. Kolber ZS, Plumley FG, Lang AS, Beatty JT, Blankenship RE, VanDover CL, et al. Contribution of aerobic photoheterotrophic bacteria to the carbon cycle in the ocean. Science. 2001:292:2492-5.

8. Oh H-M, Giovannoni SJ, Ferriera S, Johnson J, Cho J-C. Complete genome sequence of Erythrobacter litoralis HTCC2594. J Bacteriol. 2009;191:2419-20.

9. Wei J, Mao Y, Zheng Q, Zhang R, Wang Y. Erythrobacter westpacificensis sp. nov., a marine bacterium isolated from the western Pacific. Curr Microbiol. 2013;66:385-90

10. Zhuang L, Liu Y, Wang L, Wang W, Shao Z. Erythrobacter atlanticus sp. nov, a bacterium from ocean sediment able to degrade polycyclic aromatic hydrocarbons. Int J Syst Evol Microbiol. 2015;65:3714-9.

11. Zheng Q, Lin W, Liu Y, Chen C, Jiao N. A comparison of 14 Erythrobacter genomes provides insights into the genomic divergence and scattered distribution of phototrophs. Front Microbiol. 2016;7:984.

12. Yurkov V, Stackebrandt E, Holmes A, Fuerst JA, Hugenholtz P, Golecki J, et al. Phylogenetic positions of novel aerobic, bacteriochlorophyll a-containing bacteria and description of Roseococcus thiosulfatophilus gen. Nov., sp. nov., Erythromicrobium ramosum gen. Nov., sp. nov., and Erythrobacter litoralis sp. nov. Int J Syst Bacteriol. 1994;44:427-34.

13. Röling WFM, Milner MG, Jones DM, Lee K, Daniel F, Swannell RJP, et al. Robust hydrocarbon degradation and dynamics of bacterial communities during nutrient-enhanced oil spill bioremediation. Appl Environ Microbiol. 2002:68:5537-48

14. Yurkov $\vee$, Jappe J, Vermeglio A. Tellurite resistance and reduction by obligately aerobic photosynthetic bacteria. Appl Environ Microbiol. 1996;62:4195-8.

15. Hwang Y-O, Kang SG, Woo J-H, Kwon KK, Sato T, Lee EY, et al. Screening enantioselective epoxide hydrolase activities from marine microorganisms: detection of activities in Erythrobacter spp. Mar Biotechnol. 2008;10:366-73.

16. Weinbauer MG. Ecology of prokaryotic viruses. FEMS Microbiol Rev. 2004;28:127-81.

17. Suttle CA. Viruses in the sea. Nature. 2005;437:356-61.

18. Suttle CA. Marine viruses-major players in the global ecosystem. Nat Rev Microbiol. 2007;5:801-12.

19. Proctor LM, Fuhrman JA. Viral mortality of marine bacteria and cyanobacteria Nature. 1990;343:60-2.

20. Zhao Y, Temperton B, Thrash JC, Schwalbach MS, Vergin KL, Landry ZC, et al. Abundant SAR11 viruses in the ocean. Nature. 2013;494:357-60.

21. Huang S, Zhang Y, Chen F, Jiao N. Complete genome sequence of a marine roseophage provides evidence into the evolution of gene transfer agent in alphaproteobacteria. Virol J. 2011;8:124.

22. Budinoff CR. Diversity and activity of Roseobacters and roseophage. PhD dissertation. Knoxville, TN: University of Tennessee; 2012. http://trace. tennessee.edu/utk graddiss/1276. Accessed 18 Apr 2017

23. Zhan $Y$, Huang $S$, Voget $S$, Simon M, Chen F. A novel roseobacter phage possesses features of podoviruses, siphoviruses, prophages and gene transfer agents. Sci Rep. 2016;6:30372.

24. Fürch $\mathrm{T}$, Preusse $\mathrm{M}$, Tomasch J, Zech H, Wagner-Döbler I, Rabus $\mathrm{R}$, et al. Metabolic fluxes in the central carbon metabolism of Dinoroseobacter shibae and Phaeobacter gallaeciensis, two members of the marine Roseobacter clade. BMC Microbiol. 2009;9:209.
25. Pajunen M, Kiljunen S, Skurnik M. Bacteriophage $\varphi$ YeO3-12, specific for Yersinia enterocolitica serotype 0:3, is related to coliphages T3 and T7. J Bacteriol. 2000;182:5114-20.

26. Alonso MDC, Rodríguez J, Borrego JJ. Characterization of marine bacteriophages isolated from the Alboran Sea (western Mediterranean). J Plankton Res. 2002;24:1079-87.

27. Wu L-T, Chang S-Y, Yen M-R, Yang T-C, Tseng Y-H. Characterization of extended-host-range pseudo-T-even bacteriophage Kpp95 isolated on Klebsiella pneumoniae. Appl Environ Microbiol. 2007;73:2532-40.

28. Cai L, Zhang R, He Y, Feng $X$, Jiao N. Metagenomic analysis of virioplankton of the subtropical Jiulong River Estuary, China. Viruses. 2016; doi:10.3390/v8020035.

29. Hyman P, Abedon ST. Bacteriophage host range and bacterial resistance. Adv Appl Microbiol. 2010;70:217-48.

30. Lowe TM, Eddy SR. tRNAscan-SE: a program for improved detection of transfer RNA genes in genomic sequence. Nucleic Acids Res. 1997;25:955-64

31. Zhang Y, Jiao N. Roseophage RDJ $\Phi$ 1, infecting the aerobic anoxygenic phototrophic bacterium Roseobacter denitrificans OCh114. Appl Environ Microbiol. 2009;75:1745-9.

32. Zhao Y, Wang K, Jiao N, Chan F. Genome sequences of two novel phages infecting marine Roseobacters. Environ Microbiol. 2009;11:2055-64.

33. Li B, Zhang S, Long L, Huang S. Characterization and complete genome sequences of three N4-like Roseobacter phages isolated from the South China Sea. Curr Microbiol. 2016;73:409.

34. Mojica KDA, Brussaard CPD. Factors affecting virus dynamics and microbial host-virus interactions in marine environments. FEMS Microbiol Ecol. 2014;89:495-515.

35. Delisle AL, Levin RE. Characteristics of three phages infectious for psychrophilic fishery isolates of Pseudomonas putrefaciens. Antonie Van Leeuwenhoek. 1972;38:1-8.

36. Wiebe WJ, Liston J. Isolation and characterization of a marine bacteriophage Mar Biol. 1968;1:244-9.

37. Murphy J, Maphony J, Ainsworth S, Nauta A, Sinderen DV. Bacteriophage orphan DNA methyltransferases: insights from their bacterial origin, function, and occurrence. Appl Environ Microbiol. 2013;79:7547-55.

38. Kossykh VG, Schlagman SL, Hattman S. Phage T4 DNA [N $\mathrm{N}^{6}$-adenine] methyltransferase: overexpression, purification, and characterization. J Biol Chem. 1995;270:14389-93.

39. Dziewit L, Oscik K, Bartosik D, Radlinska M. Molecular characterization of a novel temperate sinorhizobium bacteriophage, $\Phi$ LM21, encoding DNA methyltransferase with CcrM-like specificity. J Virol. 2014;88:13111-24.

40. Sepúlveda-Robles O, Kameyama L, Guarneros G. High diversity and novel species of Pseudomonas aeruginosa bacteriophages. Appl Environ Microbiol. 2012;78:4510-5.

41. Liang Y, Zhang Y, Zhou C, Chen Z, Yang S, Yan C, et al. Complete genome sequence of the siphovirus Roseophage RDJLФ 2 infecting Roseobacter denitrificans OCh114. Mar Genom. 2016;25:17-9.

42. Vara L, Kana AA, Cahill JL, Rasche ES, Everett GFK. Complete genome sequence of Caulobacter crescentus Siphophage Sansa. Genom Announc. 2015;3:e01131-15

43. Wang I-N, Smith DL, Young R. Holins: the protein clocks of bacteriophage infections. Annu Rev Microbiol. 2000;54:799-825.

44. Saier MH, Reddy BL. Holins in bacteria, eukaryotes, and archaea: multifunctional xenologues with potential biotechnological and biomedical applications. J Bacteriol. 2015;197:7-17.

45. Abbasifar R, Griffiths MW, Sabour PM, Ackermann H-W, Vandersteegen K, Lavigne $R$, et al. Supersize me: Cronobacter sakazakii phage GAP32. Virology. 2014:46:138-46

46. Zago M, Scaltriti E, Rossetti L, Guffanti A, Armiento A, Fornasari ME, et al Characterization of the genome of the dairy Lactobacillus helveticus bacteriophage AAQ113. Appl Environ Microbiol. 2013;79:4712-8.

47. Hatfull GF. Complete genome sequences of 138 Mycobacteriophages. J Virol. 2012;86:2382-4.

48. Nanda AM, Thormann K, Frunzke J. Impact of spontaneous prophage induction on the fitness of bacterial populations and host-microbe interactions. J Bacteriol. 2015;197:410-9.

49. Jiao N, Zhang Y, Zeng Y, Hong N, Liu R, Chen F, et al. Distinct distribution pattern of abundance and diversity of aerobic anoxygenic phototrophic bacteria in the global ocean. Environ Microbiol. 2007;9:3091-9. 
50. Jiao N, Zhang F, Hong N. Significant roles of bacteriochlorophylla supplemental to chlorophylla in the ocean. ISME J. 2010;4:595-7.

51. Stegman MR, Cottrell MT, Kirchman DL. Leucine incorporation by aerobic anoxygenic phototrophic bacteria in the Delaware estuary. ISME J. 2014;8:2339-48.

52. Swingley WD, Sadekar S, Mastrian SD, Matthies HJ, Hao J, Ramos H, et al. The complete genome sequence of Roseobacter denitrificans reveals a mixotrophic rather than photosynthetic metabolism. J Bacteriol. 2007;189:683-90

53. Biebl $H$, Allgaier $M$, Tindall BJ, Koblizek $M$, Lünsdorf $H$, Pukall $R$, et al. Dinoroseobacter shibae gen. Nov., sp. nov., a new aerobic phototrophic bacterium isolated from dinoflagellates. Int I Syst Evol Microbiol. 2005;55: 1089-96.

Submit your next manuscript to BioMed Central and we will help you at every step:

- We accept pre-submission inquiries

- Our selector tool helps you to find the most relevant journal

- We provide round the clock customer support

- Convenient online submission

- Thorough peer review

- Inclusion in PubMed and all major indexing services

- Maximum visibility for your research

Submit your manuscript at www.biomedcentral.com/submit
Biomed Central 